Brit. J. soc. Med. (1951), 5, 223-228

\title{
ABO GROUPS OF INFANTS AND CHILDREN DYING IN THE WEST OF SCOTLAND (1949-1951)
}

\author{
BY \\ DAVID STRUTHERS \\ Department of Pathology, Royal Hospital for Sick Children, Glasgow
}

Hirszfeld and Zborowski (1925) and Levine (1943) found fewer group A children in AO families (father group A, mother group $\mathrm{O}$ ) than in OA families (father group $\mathrm{O}$, mother group A). The statistical significance of this deficiency of group A children was firmly established by Waterhouse and Hogben (1947) who reckoned that 25 per cent. of the expected number of group A children were missing from the AO families of the general population. By Bernstein's hypothesis, however, group A children are conceived with equal frequency in $\mathrm{AO}$ and in $\mathrm{OA}$ families, and it therefore follows that the missing children must have died some time between conception and childhood.

Apart from ABO iso-immunization, or some similar mechanism involving the natural alpha-antibodies carried by the mothers of AO families, all factors responsible for the loss of group A children should operate alike in AO and OA families. Thus Waterhouse and Hogben concluded that $\mathrm{ABO}$ iso-immunization was probably responsible for the deficiency of group A children observed in AO families (i.e. for the loss of about 3 per cent. of all conceptions in the general population), the total loss of life from haemolytic disease of the newborn due to Rh-sensitization being less than 0.5 per cent. of all conceptions.

The fate of the missing children has yet to be ascertained. Because ABO iso-immunization does not contribute materially to the incidence of haemolytic disease, and because the agglutinins concerned are normally present in the maternal blood early in pregnancy, Waterhouse and Hogben suggested that ABO isoimmunization acts early in foetal life, causing abortions and miscarriages. It is undoubtedly true that very few of the missing children die of haemolytic disease, but it may be argued that immaturity of the agglutinogens makes it impossible for ABO iso-immunization to act early in foetal life. Furthermore, the absence of a significant deficiency of group $\mathrm{A}$ among the newborn of group $\mathrm{O}$ mothers in a series of 2,000 births reported by Boorman (1950), and in a series of 7,856 births reported by Bryce and others (1950), suggests that some of the observed deficiency of group A children may have arisen after rather than before birth, an excess of group A children born of group $O$ mothers having died at an early age from conditions other than haemolytic disease. 
The $\mathrm{ABO}$ groups of a random series of infants and children dying before the age of 13 years are compared in this work with those of the adult population to which their parents belong.

The null hypothesis here assumes that all the missing victims of $\mathrm{ABO}$ isoimmunization die before birth, and, in this event, the frequency of group $\mathrm{O}$ should be similar among the dying offspring and among their parents. It is true that $\mathrm{ABO}$ iso-immunization may have left an excess of group $\mathrm{O}$, relative to the frequency of the corresponding gene, in the population to which the parents belong, but any deficiency of group $\mathrm{O}$ from this cause, among the offspring conceived, will be more than offset by the assumed loss of heterospecific foetuses.

Except for the remote possibility that some hitherto unsuspected mechanism may be responsible for an appreciable mortality after birth among homospecific as well as heterospecific infants of groups $\mathrm{A}, \mathrm{B}$, and $\mathrm{AB}$, the foregoing null hypothesis would be disproved by finding a significant deficiency of group $\mathrm{O}$ among the infants and children dying after birth. It would, then, follow that some, at least, of the missing victims of $\mathrm{ABO}$ iso-immunization must die after birth.

\section{Material AND Methods}

Post-mortem samples of blood were collected from 400 consecutive infants and children examined in this department between March, 1949, and March, 1951. In each case the $\mathrm{ABO}$ group was determined by the " open slide" technique, and in sixty consecutive cases the direct anti-human globulin test was applied as described by Mollison and others (1948). Apart from infectious diseases such as measles and whooping cough which generally account for very few deaths under the age of one year, most of the common causes of death under the age of 13 years in the West of Scotland are here represented.

The diagnosis of broncho-pneumonia was confirmed histologically in 148 cases in the series and includes all grades ranging from frank pulmonary suppuration to a massive haemorrhagic consolidation with minimal infiltration by polymorphonuclear cells.

In a series of 6,011 donors examined during 1948, the Glasgow and West of Scotland Blood Transfusion Service found:

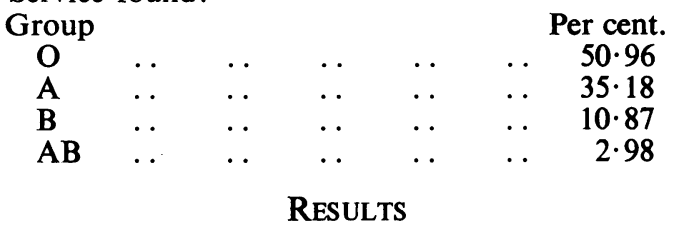

The distribution of $\mathrm{ABO}$ groups in the present series of infants and children arranged according to their ages at death is presented in Table I. Compared with the adult population to which the parents belong, there is a highly significant deficiency of group $O$ in the series, particularly among the infants dying between the ages of 4 weeks and 1 year.

Within the series there is also a highly significant difference in the frequency of group $O$ in cases with and without autopsy evidence of broncho-pneumonia (Table II). In 55 cases with no apparent abnormality other than broncho-pneumonia at autopsy the frequency of group $O$ is as low as 25.5 per cent. as against 50.0 per 
TABLE I

Numbers Autopsied as a Percentage of the Total by Age Groups

\begin{tabular}{|c|c|c|c|c|c|c|}
\hline \multirow{2}{*}{ Age at Death } & \multicolumn{4}{|c|}{ ABO Group } & \multirow{2}{*}{ Totals } & \multirow{2}{*}{$\begin{array}{c}\text { Deficiency of } \\
\text { Group O** } \\
\pm \text { Standard Error }\end{array}$} \\
\hline & 0 & $\mathbf{A}$ & B & AB & & \\
\hline Under 4 weeks & $\begin{array}{c}54 \\
(44 \cdot 3)\end{array}$ & $\begin{array}{c}41 \\
(33 \cdot 6)\end{array}$ & $\begin{array}{c}18 \\
(14 \cdot 7)\end{array}$ & $\begin{array}{c}9 \\
(7 \cdot 4)\end{array}$ & 122 & $\begin{array}{l}6 \cdot 70 \pm 4 \cdot 53 \text { per cent. } \\
t=1 \cdot 48 \\
P=0 \cdot 2\end{array}$ \\
\hline 4 weeks to 1 year & $\begin{array}{c}62 \\
(39 \cdot 2)\end{array}$ & $\begin{array}{c}71 \\
(44 \cdot 9)\end{array}$ & $\begin{array}{c}17 \\
(10 \cdot 8)\end{array}$ & $\begin{array}{c}8 \\
(5 \cdot 1)\end{array}$ & 158 & $\begin{array}{l}11 \cdot 72 \pm 3 \cdot 94 \text { percent } \\
t=2 \cdot 97 \\
P<0.01\end{array}$ \\
\hline Total 0-1 year & $\begin{array}{c}116 \\
(41 \cdot 4)\end{array}$ & $\begin{array}{c}112 \\
(40 \cdot 0)\end{array}$ & $\begin{array}{c}35 \\
(12 \cdot 5)\end{array}$ & $\begin{array}{c}17 \\
(6 \cdot 1)\end{array}$ & 280 & $\begin{array}{l}9 \cdot 53 \pm 3 \cdot 01 \text { per cent. } \\
t=3.16 \\
P<0.01\end{array}$ \\
\hline $1-2$ years & 16 & 17 & 7 & - & 40 & \\
\hline Total 0-2 years & $\begin{array}{c}132 \\
(41 \cdot 3)\end{array}$ & $\begin{array}{c}129 \\
(40 \cdot 3)\end{array}$ & $\begin{array}{c}42 \\
(13 \cdot 1)\end{array}$ & $\begin{array}{c}17 \\
(5 \cdot 3)\end{array}$ & 320 & $\begin{array}{l}9 \cdot 71 \pm 2 \cdot 83 \text { per cent. } \\
t=3 \cdot 43 \\
P<0.001\end{array}$ \\
\hline 2-13 years & $\begin{array}{c}41 \\
(51 \cdot 2)\end{array}$ & $\begin{array}{c}29 \\
(36 \cdot 3)\end{array}$ & $\begin{array}{c}8 \\
(10 \cdot 0)\end{array}$ & $\begin{array}{c}2 \\
(2 \cdot 5)\end{array}$ & 80 & $\begin{array}{l}-0.29 \pm 5 \cdot 59 \text { percent } \\
t=0.05 \\
P>0.90\end{array}$ \\
\hline Total 0-13 years & $\begin{array}{c}173 \\
(43 \cdot 3)\end{array}$ & $\begin{array}{c}158 \\
(39 \cdot 5)\end{array}$ & $\begin{array}{c}50 \\
(12 \cdot 5)\end{array}$ & $\begin{array}{c}19 \\
(4 \cdot 7)\end{array}$ & 400 & $\begin{array}{l}7 \cdot 71 \pm 2 \cdot 56 \text { per cent } \\
t=3 \cdot 01 \\
P<0.01\end{array}$ \\
\hline
\end{tabular}

* Expected frequency of Group $O=50.96 \pm 0.65$ per cent. as quoted for the adult population of the West of Scotland, 1948.

TABLE II

NUMBERS AUTOPSIED

\begin{tabular}{|c|c|c|c|c|c|}
\hline \multirow{3}{*}{ ABO Groups } & \multicolumn{5}{|c|}{ Broncho-pneumonia } \\
\hline & \multicolumn{2}{|c|}{ Present } & \multicolumn{3}{|c|}{ Absent } \\
\hline & No. & $\%$ & No. & & $\%$ \\
\hline $\begin{array}{c}\mathbf{O} \\
\mathbf{A} \\
\mathbf{B} \\
\mathbf{A B}\end{array}$ & $\begin{array}{l}47 \\
\text { Difference }=18 \\
68 \\
21 \\
12\end{array}$ & $\begin{array}{c}31 \cdot 8 \\
\cdot 24 \pm 4 \cdot 95 \text { per cent. } \\
45 \cdot 9 \\
14 \cdot 2 \\
8 \cdot 1\end{array}$ & \begin{tabular}{|r|}
126 \\
$t=3 \cdot 68$ \\
90 \\
29 \\
7
\end{tabular} & $P<0.001$ & $\begin{array}{r}50 \cdot 0 \\
35 \cdot 7 \\
11 \cdot 5 \\
2 \cdot 8\end{array}$ \\
\hline Totals & 148 & 100 & 252 & & 100 \\
\hline $\begin{array}{l}\chi^{2 *} \\
P(N=3)\end{array}$ & \multicolumn{2}{|c|}{$\begin{array}{l}28 \cdot 17 \\
<0.001\end{array}$} & \multicolumn{3}{|c|}{$\begin{aligned} & 0.21 \\
> & 0.9\end{aligned}$} \\
\hline
\end{tabular}

* Comparing each of the above distributions with that of the 6,011 donors quoted.

cent. for the cases with no broncho-pneumonia (difference $24.5 \pm 6.7$ per cent.; $t=3.7 ; \quad P<0.001)$. Furthermore, by the $\chi^{2}$ test, the chances of obtaining the individual distributions set out in Table II from a population with the ABO groups distributed as in the adult population of the West of Scotland are respectively less 
than 1 in 1,000 for cases with broncho-pneumonia and more than 900 in 1,000 for those without autopsy evidence of broncho-pneumonia. Frank pulmonary suppuration was present in 52 cases, of which 30.8 per cent. belong to group $\mathrm{O}$, the corresponding figure in 81 cases of haemorrhagic broncho-pneumonia being 28.4 per cent. This difference $(2 \cdot 4 \pm 8 \cdot 1$ per cent.; $t=0 \cdot 3 ; P<0 \cdot 9)$ is insignificant.

The higher frequency of group $\mathrm{O}$ among neo-natal deaths than among deaths between the ages of 4 weeks and 1 year in the series appears to result from a relative excess of group $O$ infants dying from conditions peculiar to the neo-natal period, i.e. from haemolytic disease of the newborn, intracranial haemorrhage, vernix pneumonia, haemorrhagic disease, and from congenital malformations inconsistent with an independent existence. In 54 such cases the frequency of group $\mathrm{O}$ is 57.4 per cent., as against 33.2 per cent. in the 68 neo-natal deaths attributable to broncho-pneumonia, infantile diarrhoea, and other conditions commonly responsible for the death of infants over the age of 4 weeks. This difference is significant (24.2 \pm 8.9 per cent.; $t=2 \cdot 7 ; P<0.01)$. Haemolytic disease of the newborn and congenital malformations account here for most of the apparent excess of group $\mathrm{O}$ infants dying from conditions peculiar to the neo-natal period.

$\mathrm{Rh}$ antibodies were found in the maternal blood in ten out of thirteen cases of haemolytic disease in the series (group O 10, group A 3). In one remaining case the infant was group $\mathrm{A}, \mathrm{Rh}$-positive, and the mother was group $\mathrm{O}, \mathrm{Rh}$-positive.

Routine histological examination revealed twelve cases of pancreatic fibrosis in the series, broncho-pneumonia being present in ten of the cases concerned. One of the group $O$ infants affected suffered from haemolytic disease, $R h$ antibodies being detected in the maternal blood. The groups of the other nine infants with pancreatic fibrosis were as follows:

$$
\begin{array}{ll}
\text { group O } & 2 \\
\text { group A } & 5 \\
\text { group B } & 2 \\
\text { group AB } 2
\end{array}
$$

Apart from known cases of haemolytic disease, the anti-human globulin tests were negative in the sixty cases examined.

Applying the distributions of the $\mathrm{ABO}$ groups among the parents to the observed numbers of group $O$ in the series, the total excess of group $A, B$, and $A B$ deaths corresponds here to roughly 15 per cent. of the series. Among the infants examined the corresponding figure is about 19 per cent.

\section{Conclusions AND Discussion}

It may be concluded from the above analysis that an association probably existed here between the antigens A and B and infant death with autopsy evidence of broncho-pneumonia.

If there is, however, an appreciable deficiency of group A children in the AO families of the West of Scotland to-day and if this deficiency is not apparent among the newborn, it follows that the mechanism of $\mathrm{ABO}$ iso-immunization described 
by Waterhouse and Hogben in the general population must have contributed to the selective mortality observed herein among infants of groups A, B, and AB dying from broncho-pneumonia or from conditions complicated by broncho-pneumonia.

The infant mortality rate for the West of Scotland, 1949-51, is probably 40-50 per 1,000 live births, and it is apparent that the observed excess of group A deaths cannot account for the loss of 25 group $\mathrm{A}$ infants per 1,000 conceptions, i.e. for 25 per cent. of the group A children expected in the AO families of the West of Scotland. Conditions excluded from the present series may be responsible for a further selective loss of group A children, but it should be observed that the 25 per cent. deficiency refers to families examined between 1927 and 1945 and hence to a population with an infant mortality rate which may have been very much higher than 50 per 1,000 live births.

Smith (1945) found a specific maternal antibody response in forty out of 46 normal heterospecific pregnancies, and it is generally agreed that the alpha-beta antibodies of the newborn are maternal in origin. There is, therefore, good reason to believe that $\mathrm{ABO}$ iso-immunization may operate to some extent in many normal heterospecific pregnancies, although it rarely causes haemolytic disease of the newborn and may even protect the $\mathrm{Rh}$-incompatible, heterospecific offspring from haemolytic disease due to Rh-sensitization.

The negative anti-human globulin tests above may indicate that the maternal alpha-beta antibodies were taken up by extra-cellular group specific receptors rather than by the foetal red cells. Alternatively, the test concerned may be specific for the antibodies in haemolytic states rather than for sensitizing antibodies in general. This alternative does not necessarily imply that the "anti-human globulin reacting" antibodies cause the associated haemolytic reaction. The destruction, by haemolysis, of red cells sensitized with some primary antibody substance may lead to the liberation of modified antibodies reacting with the anti-human globulin serum on readsorption onto circulating red cells.

Obviously many more cases must be examined to establish an association between pancreatic fibrosis and the $A B$ antigens. There seems to be no reason, however, for distinguishing here between the broncho-pneumonia in such cases and the general group of broncho-pneumonia cases to which the foregoing conclusions refer. Glanzmann (1946) and Eggimann (1949) have already suggested that $\mathrm{Rh}$ antibodies may be responsible for some cases of fibrocystic disease of the pancreas, and it is therefore conceivable that maternal-foetal incompatibility in respect of the $\mathrm{ABO}, \mathrm{Rh}$, and other antigen systems may contribute to the complex genetic pattern of infant deaths from broncho-pneumonia associated with fibrocystic disease of the pancreas.

Finally, by way of illustration, two of the possible mechanisms are outlined whereby the maternal alpha-beta antibodies may contribute to infant death from broncho-pneumonia.

(1) The maternal antibodies may diminish the resistance of heterospecific offspring to certain infections. In fibro-cystic disease of the pancreas it is thought that pancreatic 
dysfunction leads to a deficiency of vitamin A which, in turn, predisposes to bronchopneumonia. The normal pancreas is known to be unusually rich in the specific $A B$ substances and it may be that, short of actual fibrosis, a local accumulation of AB antigenantibody complexes interferes with the normal mechanism of pancreatic function.

(2) The foetal red cells may be sensitized by antibodies which do not react with the anti-human globulin serum and may -even tend to inhibit haemolytic activity, e.g. by contributing to the local balance of cholesterol compounds rather than to that of lysolecithins. Such antibodies could be responsible for a massive intravascular conglutination or agglutination reaction within the pulmonary circulation, possibly precipitated by, or else predisposing to, certain local infections. Haemorrhagic pulmonary lesions are frequently present in fatal cases of icterus gravis and it seems reasonable to suggest that the extent of any such local conglutination reaction will vary inversely with the rate at which the affected cells undergo haemolysis.

\section{SUMMARY}

According to authorities quoted, $\mathrm{ABO}$ iso-immunization is responsible for the loss of 25 per cent. of the group A children expected in AO families (father group A, mother group O), i.e. for the loss of 3 per cent. of all conceptions in the general population. It has been suggested that the children concerned die before birth. Recent surveys of the newborn and of their mothers have not, however, revealed a significant deficiency of group $\mathrm{A}$ among the newborn of group $\mathrm{O}$ mothers. It is suggested here that, in this event, many of the missing children must die after birth from conditions other than haemolytic disease.

In this work the $\mathrm{ABO}$ groups of a consecutive series of 400 infants and children autopsied in this department are compared with those of the adult population to which the parents belong. A highly significant deficiency of group $O$ (i.e. an excess of groups $\mathrm{A}, \mathrm{B}$, and $\mathrm{AB}$ ) was found in the series, particularly among the infants with autopsy evidence of broncho-pneumonia.

It was concluded that an association probably existed here between the A and B antigens and infant death from broncho-pneumonia and from conditions complicated by broncho-pneumonia. If there is, however, a deficiency of group A children in the AO families of the West of Scotland to-day, and if this deficiency is not apparent among the newborn, it follows that the mechanism of ABO isoimmunization described in the general population probably contributed to the foregoing association.

I am indebted to Dr. J. Wallace and to Mr. G. R. Milne of the Glasgow and West of Scotland Blood Transfusion Service for the necessary anti-AB and anti-human globulin sera and for the distribution of ABO groups in the adult population of the West of Scotland.

Boorman, K. E. (1950). Ann. Eug., 15, 120.

Bryce, L. M., Jakobowicz, R., McArthur, N., and Penrose, L. S. (1950). Ibid., 15, 271.

Eggimann, P. (1949). Ann. paediatr., 172, 73.

Glanzmann, E. (1946). Ibid., 166, 289.

Hirszfeld, L., and Zborowski, H. (1925). Klin. Wschr., 4, 1152.

Levine, P. (1943). J. Hered., 34, 71.

Mollison, P. L., Mourant, A. E., and Race, R. R. (1948). “The Rh Blood Groups ”, Med. Res. Coun. Mem. No. 19.

Smith, G. H. (1945). J. Path. Bact., 57, 113.

Waterhouse, J. A. H., and Hogben, L. (1947). British Journal of Social Medicine, 1, 1. 